\title{
16. PHYTOPLANKTON STRATIGRAPHY, SOUTHWEST PACIFIC, DEEP SEA DRILLING PROJECT, LEG 30
}

\author{
David Bukry, United States Geological Survey, La Jolla, California
}

\section{INTRODUCTION}

Leg 30 of the Deep Sea Drilling Project, April to June 1973, which began at Wellington, New Zealand, and ended at Apra, Guam, investigated the southwest Pacific (Figure 1), recovering 249 cores at five drilling sites, Sites 285-289. Light-microscope techniques were used to study the phytoplankton in 305 samples from these cores. Coccoliths are present most consistently; silicoflagellates and diatoms are rarely present. The zonation employed in coccolith zonal assignments of core samples (summarized in Figures 2 and 3) follows that of Bukry (1973c). Silicoflagellate and diatom zones are from Burckle (1972) and Bukry and Foster (1973).

\section{SITE SUMMARIES}

Site 285

(lat $26^{\circ} 49.16^{\prime} \mathrm{S}$, long $175^{\circ} 48.24^{\prime} \mathrm{E}$, depth $4658 \mathrm{~m}$ )

Site 285 is in the deepest area of the South Fiji Basin. A total of 14 cores was cut to a subbottom depth of 584 meters. Coccolith assemblages range in age from early middle Miocene (Core 7A) to Pliocene (Core 2). Slight to moderate solution of coccoliths is common in much of the upper section. In Core 5 ( 73 to $84 \mathrm{~m}$ ) and below, secondary calcite overgrowth on discoasters becomes progressively thicker with depth, limiting species identification. Within a diatom- and silicoflagellate-rich sediment in Cores 3 and 4 ( 36 to $65 \mathrm{~m}$ ) however, discoasters show exceptional morphologic detail (see Plate 1).

In Core 2 (17 to $27 \mathrm{~m}$ ) the upper coccolith assemblages appear to be an early Pliocene mixture. The Miocene-Pliocene boundary lies above Sample 285-2-3, 26$27 \mathrm{~cm}(20 \mathrm{~m})$, which contains Ceratolithus tricorniculatus and Triquetrorhabdulus rugosus but no Ceratolithus acutus or $C$. rugosus.

The late Miocene Discoaster neohamatus Zone assemblages of Cores 3 and 4 ( 36 to $65 \mathrm{~m}$ ) include excellently preserved discoasters and Minylitha convallis. A lack of obscuring overgrowths on such ortholithid forms as these is common in sediments rich in volcanic ash or biogenic silica. Siliceous phytoplankton are sufficiently common in Cores 3 and 4 to permit identification of the Coscinodiscus plicatus Zone of diatoms and the Dictyocha aspera Zone of silicoflagellates (Figure 4). All of these associated phytoplankton groups are represented mainly by warm-water and cosmopolitan species.

Although a few reworked specimens of Discoaster hamatus occur in Sample 285-4-1, 50-51 cm $(55 \mathrm{~m})$, the species is abundant throughout Core $5(73$ to $84 \mathrm{~m})$, where its association with Catinaster calyculus suggests assignment to the upper part of the Discoaster hamatus

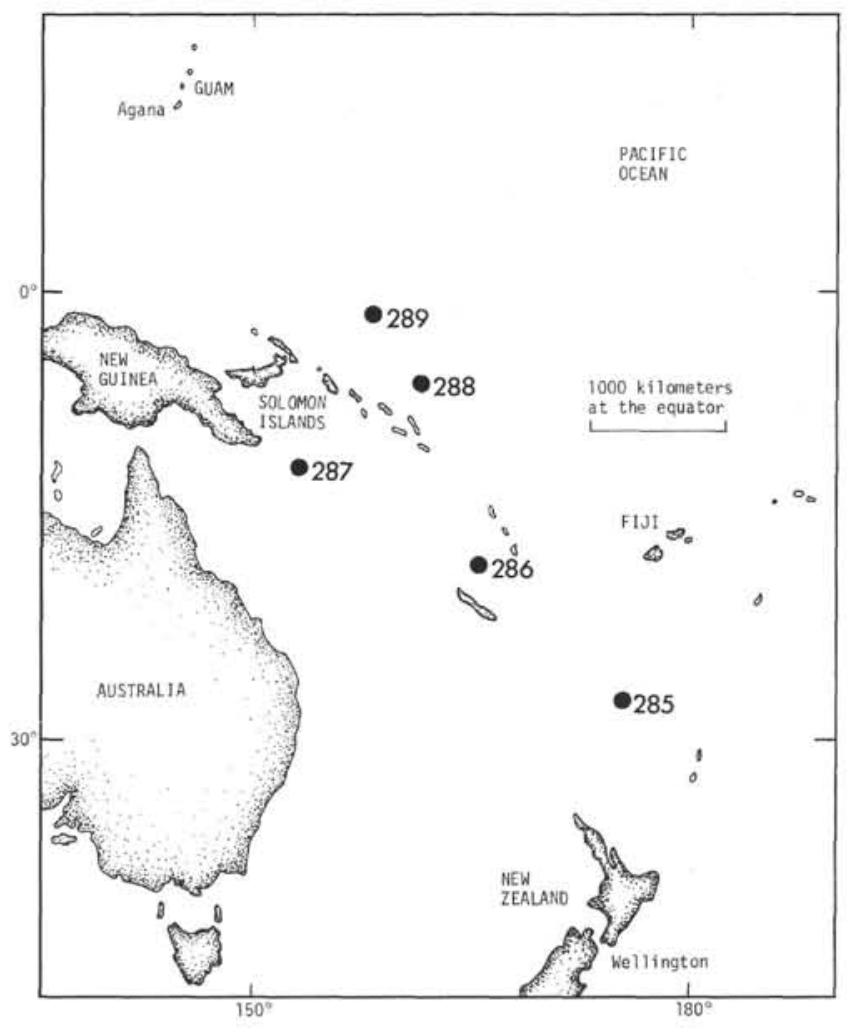

Figure 1. Sketch map showing sites drilled on DSDP Leg 30.

Zone. The oldest silicoflagellate assemblage at Site 285 is present near the base of Core 5 (Figure 4). Rare occurrences of Corbisema triacantha and Distephanus sp. cf. D. longispinus suggest assignment of the assemblage to the latest part of the Distephanus longispinus Zone.

The oldest definitive coccolith assemblage of Sample $285 \mathrm{~A}-7 \mathrm{~A}-2,85-86 \mathrm{~cm}(558 \mathrm{~m})$ is assigned to the early middle Miocene Sphenolithus heteromorphus Zone on the basis of the presence of Cyclicargolithus floridanus, Cyclococcolithina macintyrei, Discoaster sp. cf. D. deflandrei, D. sp. cf. D. variabilis, and Sphenolithus heteromorphus. A sample from the bottom section of Core 7 contains only a few thickly overgrown species, including some that are probably reworked such as Dictyococcites bisectus and Discoaster sp. cf. D. druggii. Correlation of the sample is based on the occurrence of short-ranging Sphenolithus heteromorphus (Figure 2).

Site 286

(lat $16^{\circ} 31.92$ 'S, long $166^{\circ} 22.18^{\prime} \mathrm{E}$, depth $4465 \mathrm{~m}$ )

Site 286 is between the north and south New Hebrides trenches. A total of 41 cores were cut to a depth of 706 


\begin{tabular}{|c|c|c|c|c|c|c|c|}
\hline \multirow{2}{*}{$\begin{array}{l}\text { Series or } \\
\text { Subseries }\end{array}$} & \multirow[b]{2}{*}{ Zone } & \multirow[b]{2}{*}{ Subzone } & \multicolumn{5}{|c|}{ Sites } \\
\hline & & & 285 & 286 & 287 & 288 & 289 \\
\hline Holocene & \multicolumn{2}{|l|}{ Emiliania huxleyi } & & & $1-2 / 2-2$ & & \\
\hline \multirow{3}{*}{ Pleistocene } & \multicolumn{2}{|l|}{ Gephyrocapsa oceanica } & & $1-2 / 2-2$ & $3-1$ & $1-1 / 1-2$ & $1-1 / 2-2$ \\
\hline & \multirow{2}{*}{ Crenalithus doronicoides } & Gephyrocapsa caribbeanica & & \multirow{8}{*}{$? 4-1$} & & \multirow{4}{*}{$5-3 / 5-6 a^{? 2-2 / 4-1}$} & $3-2 / 4-4$ \\
\hline & & Emiliania annula & & & & & $4-5 / 4-6$ \\
\hline \multirow{3}{*}{$\begin{array}{c}\text { Upper } \\
\text { Pliocene }\end{array}$} & \multirow{3}{*}{ Discoaster brouweri } & Cyclococcolithina macintyrei & & & $6-2$ & & $5-1 / 6-3$ \\
\hline & & Discoaster pentaradiatus & & & $7-1$ & & $6-6 / 8-6$ \\
\hline & & Discoaster tamalis & & & & & $9-3 / 9-6$ \\
\hline \multirow{4}{*}{$\begin{array}{r}\text { Lower } \\
\text { Pliocene }\end{array}$} & \multirow{2}{*}{ Reticulofenestra pseudoumbilica } & Discoaster asymmetricus & \multirow{4}{*}{$2-1 / 2-2$} & & & & \multirow{2}{*}{$\begin{array}{c}10-3 \\
11-3 / 15-3\end{array}$} \\
\hline & & Sphenolithus neoabies & & & & & \\
\hline & & Ceratolithus rugosus & & & & & \\
\hline & Ceratolithus tricorniculatus & Ceratolithus acutus & & & & & $16-3$ \\
\hline & & Triquetrorhabdulus rugosus & $2-3$ & & & & $16-6 / 17-1$ \\
\hline $\begin{array}{l}\text { Upper } \\
\text { Miocene }\end{array}$ & & Ceratolithus primus & $2-4$ & & & & $17-2 / 22-3$ \\
\hline & Discoaster quinqueramus & Discoaster berggrenii & & & & $6-3$ & $23-5 / 27-3$ \\
\hline & Discoaster neohamatus & Discoaster neorectus & & & & & $27-6 / 34-1$ \\
\hline & Discoaster neohamatus & Discoaster bellus & $3-1 / 4-6$ & & & $6-6$ & $27-6 / 34-1$ \\
\hline & Discoaster hamatus & & $5-1 / 5-6$ & & & $7-2 / 8-1$ & $34-3 / 37-3$ \\
\hline $\begin{array}{c}\text { Midale } \\
\text { Miocene }\end{array}$ & Catinaster coalitus & & & & & & $? 38-3 / 39-5$ \\
\hline & & Discoaster kugleri & $1 \mathrm{~A}-2$ & & & $9-1$ & $40-3$ \\
\hline & Discoaster exilis & Coccolithus miopelagicus & $2 \mathrm{~A}-1 / 5 \mathrm{~A}-1$ & & & $10-2$ & $41-2 / 47-3$ \\
\hline & Sphenolithus heteromorphus & & $6 \mathrm{~A}-1 / 7 \mathrm{~A}-2$ & & & & $48-3 / 52-6$ \\
\hline & Helicopontosphaera ampliaperta & & ?7A-6 & & & & $53-3 / 57-3$ \\
\hline Lower & Sphenolithus belemnos & & & & & & $58-3 / 61-3$ \\
\hline Miocene & & Discoaster druggii & & & & & \\
\hline & Triquetrorhabdulus carinatus & Discoaster deflandrei & & & & $11-2 / 2 A-2$ & $61-6 / 82-3$ \\
\hline & & Cyclicargolithus abisectus & & & & & \\
\hline & Sphenolithus ciperoensis & & & $6-2 / 6-5$ & & $3 \mathrm{~A}-2$ & $83-2 / 85-1$ \\
\hline & Sphenolithus distentus & & & & $10-4$ & & $86-2 / 91-3$ \\
\hline Oligocene & Sphenolithus predistentus & & & $7-6$ & & $5 \mathrm{~A}-1 / 6 \mathrm{~A}-1$ & $93-3 / 100-1$ \\
\hline & & Reticulofenestra hillae & & $8-2$ & & & \\
\hline & Helicopontosphaera reticulata & Coccolithus formosus & & & & & $101-2 / 102-1$ \\
\hline & & Coccolithus subdistichus & & $9-2 / 10-1$ & & & \\
\hline Upper Eocene & Discoaster barbadiensis & & & $10-4 / 17-2 ; ? 18-1$ & & & $103-1 / 108-1$ \\
\hline & Reticulofenestra umbilica & Discoaster saipanensis & & $19-1 / 33-2$ & & & $109-1$ \\
\hline & Kenculojenestra umbilica & Discoaster bifax & & & & & $? 111-1$ \\
\hline Middle & & Coccolithus staurion & & & & & \\
\hline Eocene & Nannotetrina quadrata & Chiasmolithus gigas & & & $11-2$ & & \\
\hline & & Discoaster strictus & & & $12-1 / 14-2$ & & $? 111-3 / 113-1$ \\
\hline & & Rhabdosphaera inflata & & & $15-1 / 15-2$ & & \\
\hline & Discoaster sublodoensis & Discoasteroides kuepperi & & & & & \\
\hline Lower & Discoaster lodoensis & & & & & & \\
\hline Eocene & Tribrachiatus orthostylus & & & & & & \\
\hline & Discoaster diastypus & & & & $16-1$ & & \\
\hline
\end{tabular}


PHYTOPLANKTON STRATIGRAPHY

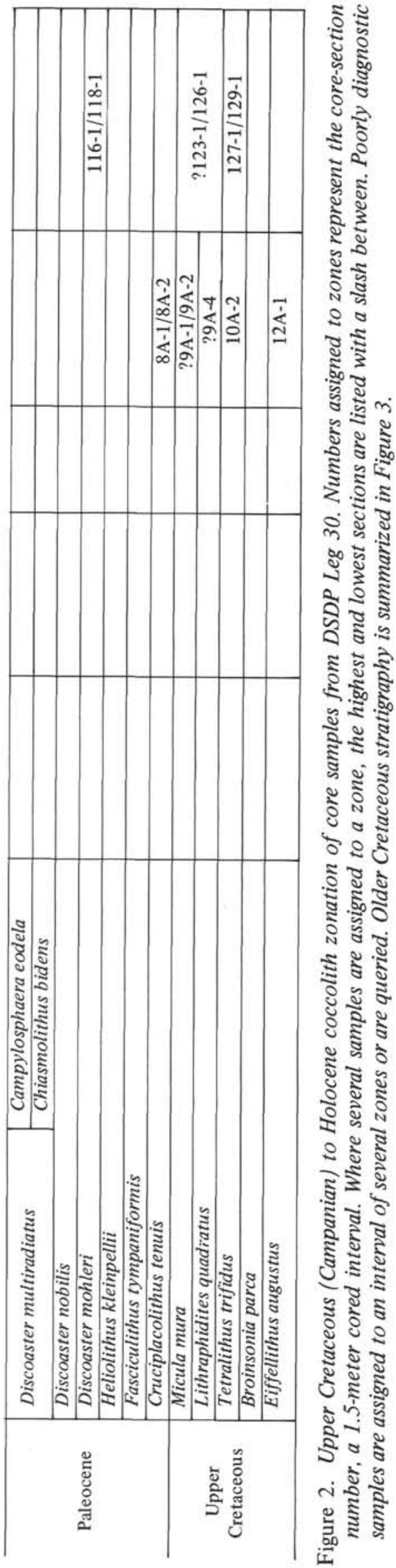

\begin{tabular}{|c|c|}
\hline Stage & Site 288 \\
\hline Santonian to Turonian & $13 \mathrm{~A}-1 / 14 \mathrm{~A}-1$ \\
Turonian & $15 \mathrm{~A}-1$ \\
Albian to Turonian & $23 \mathrm{~A}-2 / 20 \mathrm{~A}-1$ \\
Albian & $24 \mathrm{~A}-1 / 25 \mathrm{~A}-1$ \\
Aptian or Albian & $26 \mathrm{~A}-1$ \\
$?$ & $27 \mathrm{~A}-2 / 30 \mathrm{~A}-1$ \\
\hline
\end{tabular}

Figure 3. Pre-Campanian Cretaceous coccolith stratigraphy of Site 288 .

meters. Basalt was cored in Cores 36 to 41 (649 to 706 $\mathrm{m})$. Coccolith samples range in age from late middle Eocene in Core 33 (606 to $615 \mathrm{~m}$ ) to late Pleistocene in Core $1(0$ to $7 \mathrm{~m})$. The greater part of the cored section, Cores 8 to 33 (131 to $615 \mathrm{~m}$ ), sampled a thick interval of late middle Eocene, late Eocene, and earliest Oligocene.

Diatoms and silicoflagellates occur only in Core 1. In Sample 286-1-2, 90-91 cm (17 m), Dictyocha stapedia dominates among the silicoflagellates, Ethmodiscus rex among the diatoms. A count of 100 silicoflagellates shows $90 \%$ Dictyocha stapedia, $5 \%$ D. epiodon, $4 \%$ Octactis pulchra, and 1\% Distephanus sp. cf. D. speculum, an assemblage that indicates the late Pleistocene Dictyocha epiodon Zone. The diatom assemblage contains the warm-water Pleistocene guide species Pseudoeunotia doliolus, which indicates the Pleistocene Pseudoeunotia doliolus Zone. Other diatoms present include Asteromphalus heptactis, A. imbricatus, Bacteriastrum sp., Coscinodiscus africanus, C. excentricus, C. lineatus, Diploneis sp., Nitzschia marina, Rhizosolenia bergonii, $R$. styliformis, Thalassionema sp., and Thalassiosira oestrupii. Reworking from older strata is most clearly demonstrated in the assemblage of Miocene and Pliocene discoasters that includes Catinaster coalitus, Discoaster deflandrei, $D$. quinqueramus, D. surculus, and $D$. variabilis, among other species.

Siliceous phytoplankton are less abundant in deeper samples from Core 1 but provide evidence for a Pleistocene age. Sample 286-1-4, 110-111 cm (3 m), for example, contains rare Dictyocha stapedia, Octactis pulchra, Ethmodiscus rex, Hemidiscus cuneiformis, Nitzschia marina, Rhizosolenia bergonii, and Roperia tesselata. In $286-1-5,30-31 \mathrm{~cm} \mathrm{(4} \mathrm{m),} \mathrm{a} \mathrm{count} \mathrm{of} 100$ silicoflagellates shows 96\% Dictyocha stapedia, 3\% Distephanus speculum varians, and $1 \%$ Dictyocha epiodon.

Sample 286-2-2, 60-61 cm (19 m) contains a good assemblage of the Gephyrocapsa oceanica Zone of coccoliths, which includes Ceratolithus cristatus, Emiliania annula, Gephyrocapsa oceanica, and G. sinuosa.

The early Oligocene Helicopontosphaera reticulata Zone coccolith assemblages of Cores 8 to 10 (133 to 169 m) are distinctive in the common occurrence of Coccolithus subdistichus sensu amplo. Discoaster gartneri and Helicopontosphaera reticulata, generally missing in open-ocean deposits of this zone, occur together in Sample 286-9-2, 50-51 cm $(151 \mathrm{~m})$. Samples lower in the zone contain intensively etched (-3) placoliths but only slightly etched (-1) discoasters (preservation code follows Bukry, 1973b). Although C. subdistichus is missing in Sample $286-9-5,50-51 \mathrm{~cm}(156 \mathrm{~m})$, the presence of 


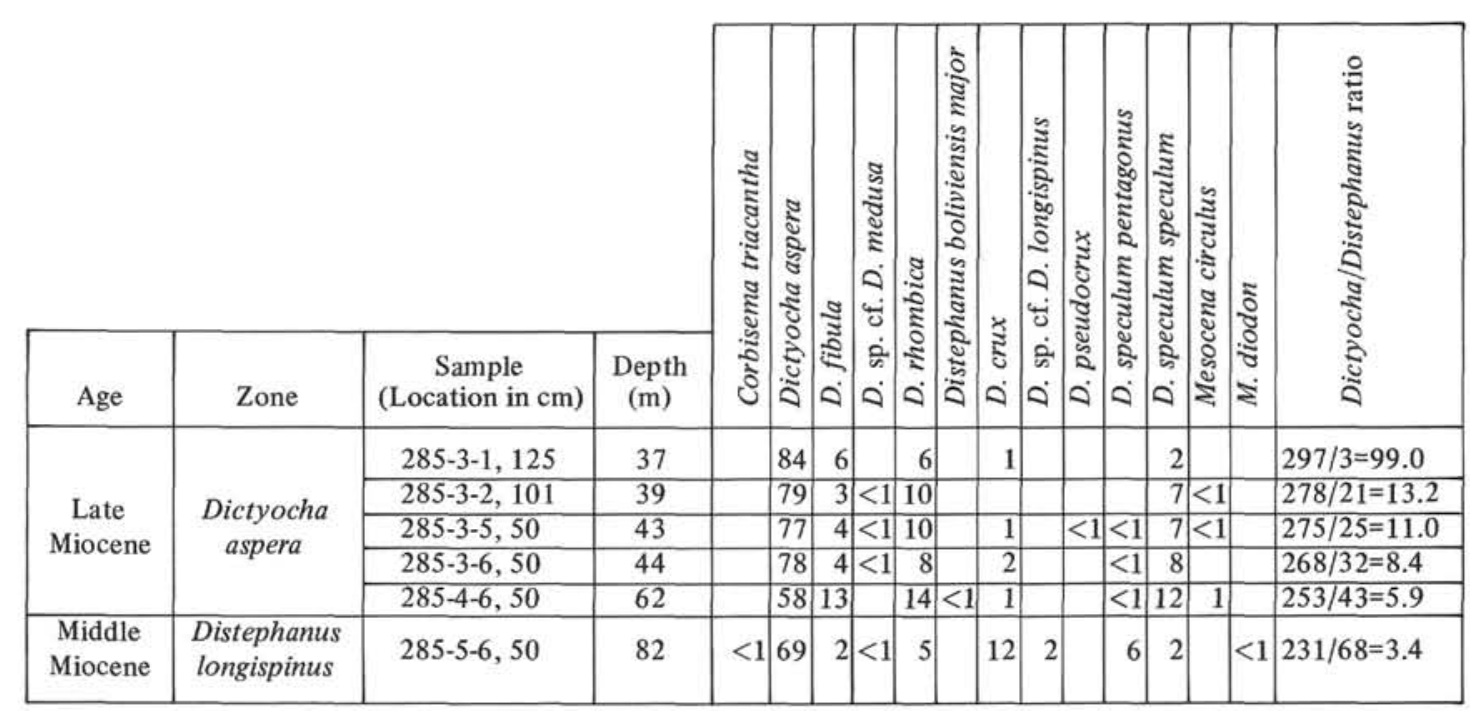

Figure 4. Occurrence, expressed as percentages, of silicoflagellates at Site 285. Percentages based on counts of 300 specimens per sample. The increasing ratio of Dictyocha to Distephanus suggests warmer paleotemperatures with decreasing age (Mandra, 1969).

Isthmolithus recurvus and the absence of rosette discoasters suggests the Coccolithus subdistichus Subzone. Sample 286-10-1, 66-67 cm (169 m), immediately below, contains both $C$. subdistichus and I. recurvus.

Late Eocene coccolith assemblages with the distinctive species Discoaster saipanensis, Isthmolithus recurvus, and Reticulofenestra reticulata occur in Sample 286-10-4, 50-51 cm (174 m). Coccolith assemblages are moderately etched $(-2$ or -3$)$ in the late Eocene of Cores 10 to 17 (169 to $311 \mathrm{~m}$ ). Several samples, such as 286-122, 60-61 cm (208 m) and 286-14-2, 50-51 cm (246 m), contain Helicopontosphaera reticulata.

Moderate etching and fragmentation of coccoliths are typical in the late middle Eocene of Cores 19 to 33 (340 to $615 \mathrm{~m}$ ). The species array in this interval is fairly uniform and suggests a high rate of sedimentation during a brief period near the end of the middle Eocene. All 11 samples examined contain species suggesting assignment to the upper Discoaster saipanensis Subzone, an interval probably representing less than 2 m.y. (Bukry, 1973b). A sedimentation rate greater than 137 bubnoffs $(\mu \mathrm{m} / \mathrm{yr}$, $\mathrm{mm} / 10^{3} \mathrm{yr}$, or $\mathrm{m} / 10^{6} \mathrm{yr}$ ) is indicated. An abundance of volcanogenic detritus and deposition in graded beds, described by shipboard scientists, accounts for the high sedimentation rate. The occurrence of Helicopontosphaera heezenii and Pemma papillatum in 286-29-2, 79$80 \mathrm{~cm}(531 \mathrm{~m})$ probably suggests reworking from shallower areas.

Samples examined from Cores 34 and 35 (625 to 649 $\mathrm{m})$, just above basalt, are nonfossiliferous.

\section{Site 287}

(lat $13^{\circ} 54.67^{\prime} \mathrm{S}$, long $153^{\circ} 15.93^{\prime} \mathrm{E}$, depth $4632 \mathrm{~m}$ )

Site 287 is in the Coral Sea Basin southeast of New Guinea. Coccolith assemblages range in age from earliest Eocene for material just above basalt in Core 16 (236 to $238 \mathrm{~m})$ to Holocene in Core $1(0$ to $8 \mathrm{~m})$.

Late Quaternary coccolith assemblages are well preserved in samples from Cores 1 and 2. Core 1 con- tains such species as Cyclococcolithina leptopora, Emiliania huxleyi, Gephyrocapsa caribbeanica, G. sp. cf. G. ericsonii, G. oceanica, G. omega, Helicopontosphaera wallichii, Rhabdosphaera claviger, Umbilicosphaera sibogae, and some displaced Sphenolithus abies.

The late Pleistocene Gephyrocapsa oceanica Zone of Sample 287-3-1, 105-106 cm (37 m) contains an abundance of excellently preserved Emiliania annula. Other species present include Ceratolithus cristatus, Discolithina japonica, Emiliania ovata, Gephyrocapsa oceanica, Helicopontosphaera kamptneri, Rhabdosphaera claviger, $R$. stylifer, and some displaced Discoaster brouweri and Sphenolithus abies.

The middle Eocene Nannotetrina quadrata Zone of Cores 11 to 14 (179 to $217 \mathrm{~m}$ ) contains abundant coccoliths throughout. Diatoms and radiolarians are common and silicoflagellates sparse in part of the interval, Samples 287-12-4, 50-51 cm to 287-11-6, 14-15 cm (188 to $195 \mathrm{~m})$. A comparison of the coccolith paleotemperature indicating ratio of Discoaster/Chiasmolithus (Bukry, 1973a) between Sample 287-12-4, which contains siliceous phytoplankton, and 287-13-2, which contains no siliceous phytoplankton, shows the same ratio, or no significant paleotemperature change. Other nonsiliceous middle Eocene assemblages in Cores 11 and 13 do show higher Discoaster/Chiasmolithus ratios that indicate warmer temperatures and probably reduced upwelling (Figure 5).

Rosette discoasters flourished in the late Paleocene and Eocene but became extinct in the late Eocene, leaving nonrosette discoasters to dominate the cooler Oligocene. Fluctuations in the relative abundance of rosette species such as Discoaster barbadiensis and nonrosette species such as $D$. distinctus were determined to test for possible paleotemperature significance. The results of counts of 300 for the warmest and coolest middle Eocene assemblages, as suggested by the Discoaster/Chiasmolithus ratio, show mixed correlations suggesting no paleotemperature significance for the rosette/nonrosette discoaster ratio (Figure 5). 


\begin{tabular}{|c|c|c|c|c|}
\hline Age & $\begin{array}{c}\text { Sample } \\
\text { (Interval in } \mathrm{cm} \text { ) }\end{array}$ & $\begin{array}{l}\text { Depth } \\
\text { (m) }\end{array}$ & $\begin{array}{c}\text { Discoaster/ } \\
\text { Chiasmolithus }\end{array}$ & $\begin{array}{l}\text { Rosette discoaster/ } \\
\text { Nonrosette discoaster }\end{array}$ \\
\hline 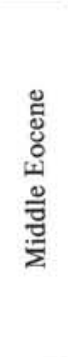 & $\begin{array}{l}11-2,50-51 \\
11-4,50-51 \\
11-5,50-51 \\
11-6,14-15 \\
12-1,100-101 \\
12-2,50-51 \\
12-3,50-51 \\
12-4,50-51 \\
13-2,50-51 \\
14-2,50-51\end{array}$ & $\begin{array}{l}181 \\
185 \\
187 \\
188 \\
190 \\
191 \\
193 \\
195 \\
199 \\
209\end{array}$ & $\begin{array}{l}75 / 25 \\
81 / 19 \\
84 / 16 \\
57 / 43 \\
45 / 55 \\
58 / 42 \\
55 / 45 \\
52 / 48 \\
52 / 48 \\
60 / 40\end{array}$ & $\begin{array}{l}81 / 19 \\
69 / 31 \\
52 / 48 \\
67 / 33\end{array}$ \\
\hline
\end{tabular}

Figure 5. Discoaster/Chiasmolithus ratio based on counts of 300 specimens in a sequence of samples at Site 287. Higher ratios indicate warmer paleotemperatures. Rosette/nonrosette discoaster ratios for selected samples show no correlation to paleotemperatures.

Rare silicoflagellates occur in the upper four sections of Core 12 (190 to $195 \mathrm{~m}$ ). The composite assemblage includes Corbisema hastata minor, C. triacantha, Dictyocha sp. cf. $D$. deflandrei, Naviculopsis foliacea; and $N$. constricta. Corbisema triacantha and Dictyocha sp. cf. D. deflandrei occur only in the sample showing the greatest diversity, $287-12-4,50-51 \mathrm{~cm}$. The specimens of $D$. sp. cf. $D$. deflandrei differ from those of the Oligocene by having a basal ring with sulcate inner margins, as illustrated by Glezer (1966, pl. 12, fig. 14-19).

The coccolith Rhabdosphaera inflata, associated with Discoaster sublodoensis, Ellipsolithus lajollaensis, Reticulofenestra dictyoda, and Triquetrorhabdulus inversus in Sample 287-15-1, 89-90 cm (217 m), indicates the upper portion of the Discoaster sublodoensis Zone. The deepest sample available, 287-16-1, 43-44 cm (236 m), contains coccoliths of the lower Discoaster diastypus Zone, as indicated by the presence of Chiasmolithus bidens, Discoaster sp. cf. $D$. diastypus, $D$. lenticularis, $D$. multiradiatus, D. sp. cf. D. nobilis, and Tribrachiatus $\mathrm{sp}$. cf. $T$. contortus, among other species.

\section{Site 288}

(lat $5^{\circ} 58.35$ 'S, long $161^{\circ} 49.53^{\prime} \mathrm{E}$, depth $3000 \mathrm{~m}$ )

Site 288 is on the Ontong-Java Plateau, a shallow area northeast of New Guinea. A total of 43 cores was cut discontinuously through a 989-meter section that ranged in age from Early Cretaceous to Quaternary on the basis of coccoliths.

Coccoliths are the dominant fossil group through the section; silicoflagellates and diatoms occur only in Core $1(0$ to $3 \mathrm{~m})$. Silicoflagellates are rare; only two species are present: Dictyocha epiodon and D. stapedia. Diatoms are most common, though solution thinned, in Sample $288-1-2,50-51 \mathrm{~cm}(2 \mathrm{~m})$, where species present include Coscinodiscus africanus, C. excentricus, C. nodulifer, Hemidiscus cuneiformis, Nitzschia marina, Pseudoeunotia doliolus, Rhizosolenia bergonii, and Thalassiothrix longissima. Coccolith assemblages in these late Pleistocene samples are noteworthy for the very common occurrence of Ceratolithus and Gephyrocapsa.

Samples from Cores 2 to 4 ( 10 to $58 \mathrm{~m}$ ) contain coccolith assemblages that are chaotic mixtures of late Miocene and Pliocene species. They lack Gephyrocapsa and occur above latest Pliocene assemblages of Core 5; therefore, the Core 2 to Core 4 samples are probably latest Pliocene to earliest Pleistocene. Significant erosion during that time is suggested by the common occurrence of a full array of late Miocene to Pliocene discoasters.

A series of discontinuous cores (6 to 11) sampled various zones and subzones through the Miocene between 86 and 238 meters. Typical of tropical Miocene coccolith ooze, discoasters are abundant and moderately $(+2)$ overgrown. For comparative studies, Miocene discoasters are much less overgrown at Site 288 than at nearby Site 289 , where specimens show thick, irregular overgrowth $(+3$ and +4$)$.

Oligocene assemblages of Cores $2 \mathrm{~A}$ to $6 \mathrm{~A}$ (305 to 467 m) contain abundant discoasters and sphenoliths and are slightly more overgrown $(+3)$ than Miocene assemblages. The dominance of Discoaster and Sphenolithus indicates tropical waters (Bukry, 1973b) and the absence of any marginal-marine indicators such as Peritrachelina, Braarudosphaera, or even Helicopontosphaera indicates deep-ocean deposition.

Core 7A at 495 meters was void of sediment, and Core $8 \mathrm{~A}$ at 533 meters recovered only 2 meters of early Paleocene coccolith ooze. Zonal assignment of the two samples from this core raises some question of zone definitions. The Cruciplacolithus tenuis Zone as originally defined by Mohler and Hay (1967) is simply recognized as the interval between the first occurrence of two widespread and distinctive species, Cruciplacolithus tenuis at the base and Fasciculithus tympaniformis at the top. This definition has proved to be useful in Paleocene sections and does not preclude the occurrence of other species of Fasciculithus such as F. magnus at DSDP 47.2 and $F$. pileatus at Site 288, which precede $F$. tympaniformis. The earliest occurrences of Ellipsolithus macellus and Cyclococcolithina? robusta have been suggested as guide fossils for zones and subzones occupying the upper part of the original $C$. tenuis Zone (see Martini, 1970; Gartner, 1971). Sample 288A-8-2, $68-69 \mathrm{~cm}(534 \mathrm{~m})$ contains $C$. tenuis, C.? robusta, Ellipsolithus sp., and $F$. pileatus and is therefore assigned to the upper part of the C. tenuis Zone of Mohler and Hay (1967). Gartner's (1971) C. ? robusta Zone (=subzone) would seem an appropriate subzonal designation. 
Coccoliths are common to abundant in Cretaceous samples from Cores 9A to 30A (571 to $989 \mathrm{~m})$. Maestrichtian assemblages lack Broinsonia parca, Lithraphidites quadratus, or Micula mura sensu stricto. Some coccolith specimens resembling $M$. mura occur in Sections 1 and 2 of Core 9A. The highest occurrence of Broinsonia parca and Tetralithus trifidus, indicating late Campanian or early Maestrichtian, is in Core 10 (200 to $210 \mathrm{~m}$ ). The early Campanian assignment of 288A-12-1, $118-120 \mathrm{~cm}(686 \mathrm{~m})$, is based on the presence of Broinsonia parca, Eiffellithus augustus, and Tetralithus aculeus.

Below this level, coccolith oozes have undergone diagenesis and generally lack the biostratigraphic zonal guide fossils used to suggest marginal-marine zonations. No specimens of Marthasterites, Braarudosphaera, Kamptnerius, or Corollithion are identified; therefore, only general stage assignments based on such taxa as Gartnerago obliquum (Core 14A), Tetralithus pyramidus (Cores 13A to 15A), and Chiastozygus disgregatus (Core 14A) are possible for these open-ocean assemblages.

In samples of limestone from Core 20 and below ( 847 to $989 \mathrm{~m}$ ), only the most diagenetically resistant species were found. These species are dominated by Watznaueria barnesae and include Chiastozygus sp., Eiffellithus turriseiffeli, Manivitella pemmatoidea, Parhabdolithus embergeri, Zygodiscus bicrescenticus, and Z. compactus.

The first occurrence of E. turriseiffeli is in Core 26A, but this may be a function of the much poorer preservation in the deeper cores. An age of Aptian or Albian or younger is indicated for the basal cores. Other guide fossils for the Aptian and early Albian, such as Parhabdolithus angustus and Prediscosphaera cretacea, or Lithraphidites alatus for the Cenomanian (Roth, 1973), are missing. The lowest occurrence of $P$. cretacea is in Core 20 ; its absence in deeper samples suggests that it is probably more susceptible to removal by diagenesis than Eiffellithus turriseiffeli.

\section{Site 289 \\ (lat $0^{\circ} 29.92$ 'S, long $158^{\circ} 30.69^{\prime} \mathrm{E}$, depth $2206 \mathrm{~m}$ )}

Site 289 on the Ontong-Java Plateau was completely cored from the sea floor to extrusive basaltic basement $(0$ to $1261 \mathrm{~m})$. Although coccoliths indicate essentially continuous accumulation of sediment from late middle Eocene to Quaternary, preservation is much poorer at this site than at Site 288. Discoaster specimens in particular have irregular, moderate $(+2,+3)$ to heavy $(+3$, $+4)$ overgrowth throughout the pre-Pliocene section of Cores 16 to 118 (150 to $1112 \mathrm{~m}$ ), making identifications difficult in many samples. No significant siliceous phytoplankton assemblages were observed in coccolith smear-slide preparations. Only rare, solution-thinned, and fragmented specimens occur at some levels in the Sphenolithus predistentus Zone, Discoaster neohamatus Zone, and Pliocene to Quaternary.

The coccolith assemblages are those of a tropical shallow ocean area. Discoaster and Sphenolithus are abundant, and Hayaster, Scyphosphaera, Discolithina, and Oolithotus more common than at deep-ocean sites.
Low-latitude coccolith zonation is applicable through the cored interval, although the marker species of Ceratolithus in the upper Miocene and lower Pliocene are sparse. One problem interval, the Triquetrorhabdulus carinatus Zone overlapping the Oligocene-Miocene boundary, requires reexamination of species and zonal definitions because one of the key marker species, Discoaster druggii, appears to be discontinuous in its distribution.

The Triquetrorhabdulus carinatus Zone is especially thick at Site 289, occurring in Cores 61 to 82 (579 to 773 $\mathrm{m})$. Discoaster druggii is most common in samples from Cores 71 and 61 and rare or absent in intervening samples. This uneven distribution suggests a major ecologic control of $D$. druggii that would make its use in discontinuously cored sections difficult. $D$. druggii has been used as a biostratigraphic guide because it is a large and distinctively shaped species that can be detected at very low abundance levels. But its intermittent distribution through the upper part of the zone here and at Sites 214 and 238 suggests potential correlation irregularities resulting from false first occurrences. Detailed studies of the phylogeny, morphotypes, and biogeography of $D$. druggii from many sections are needed to improve the biostratigraphic subdivision of the lower Miocene by coccoliths.

The deepest sample available, $289-129-1,127-128 \mathrm{~cm}$ $(1212 \mathrm{~m})$, is a limestone containing an abundant, overgrown coccolith assemblage of probable late Campanian age that includes Broinsonia bevieri, B. parca, Cretarhabdus crenulatus, Cribrosphaera sp. cf. C. ehrenbergii, Manivitella pemmatoidea, Prediscosphaera cretacea, Tetralithus pyramidus, T. trifidus, and Watznaueria barnesae.

\section{REFERENCES}

Bukry, D., 1973a. Coccolith and silicoflagellate stratigraphy, Tasman Sea and southwestern Pacific Ocean, Deep Sea Drilling Project Leg 21. In Burns, R.E., Andrews, J.E., et al, Initial Reports of the Deep Sea Drilling Project, Volume 21: Washington (U.S. Government Printing Office), p. 885893.

1973b. Coccolith stratigraphy, eastern equatorial Pacific, Leg 16 Deep Sea Drilling Project. In van Andel, T.H., Heath, H.R., et al., Initial Reports of the Deep Sea Drilling Project, Volume 16: Washington (U.S. Government Printing Office), p. 653-711.

1973c. Low-latitude coccolith biostratigraphic zonation. In Edgar, N.T., Saunders, J.B., et al., Initial Reports of the Deep Sea Drilling Project, Volume 15: Washington (U.S. Government Printing Office), p. 685703.

Bukry, D. and Foster, J.H., 1973. Silicoflagellate and diatom stratigraphy, Leg 16, Deep Sea Drilling Project. In van Andel, T.H., Heath, G. R., et al, Initial Reports of the Deep Sea Drilling Project, Volume 16: Washington (U.S. Government Printing Office), p. 815-871.

Burckle, L.H., 1972. Late Cenozoic planktonic diatom zones from the Eastern Equatorial Pacific: Nova Hedwigia Beihefte, v. 39, p. 217-246.

Gartner, S., Jr., 1971. Calcareous nannofossils from the JOIDES Blake Plateau cores and revision of Paleogene 
nannofossil zonation: Tulane Stud. Geol. Paleontol., v. 8 , p. 101-121.

Glezer, Z.I., 1966. Silicoflagellatophyceae. In Gollerbakh, M.M. (Ed.), Cryptogamic plants of the U.S.S.R.: Akad. Nauk SSSR, V.A. Komarova Bot. Inst. (Translated from Russian by Israel Program for Scientific Translations Ltd., Jerusalem, 1970), v. 7, p. 1-363.

Mandra, Y.T., 1969. Silicoflagellates: a new tool for the study of Antarctic Tertiary climates: U.S. Antarctic J., v. 4, p. 172-174.
Martini, E., 1970. Standard Paleogene calcareous nannoplankton zonation: Nature, v. 226, p. 560-561.

Mohler, H.P. and Hay, W.W., 1967. Zonation of the Paleocene-lower Eocene interval: Gulf Coast Assoc. Geol. Soc. Trans., v. 17, p. 432-437.

Roth, P.H., 1973. Calcareous nannofossils-Leg 17, Deep Sea Drilling Project. In Winterer, E.L., Ewing, J.I., et al., Initial Reports of the Deep Sea Drilling Project, Volume 17: Washington (U.S. Government Printing Office), p. 695795. 


\section{PLATE 1}

Miocene Phytoplankton Site 285

(Figures 1-5 magnified 1000×; scale bar $10 \mu \mathrm{m}$ )

(Figures 6-16 magnified $700 \times$; scale bar $10 \mu \mathrm{m}$ )

Figure 1 Discoaster hamatus Martini and Bramlette; 285-5$6,50-51 \mathrm{~cm}(82 \mathrm{~m})$.

Figure 2 Discoaster neohamatus Bukry and Bramlette; 285$3-1,125-126 \mathrm{~cm}(37 \mathrm{~m})$.

Figures 3, 4 Discoaster pansus (Bukry and Percival); 285-3-1, $125-126 \mathrm{~cm}(37 \mathrm{~m})$.

Figure 5 Discoaster sp. aff. D. variabilis Martini and Bramlette; 285-3-1, 125-126 cm (37 m).

Figures 6-8 Coscinodiscus plicatus Grunow.

6. $285-3-1,125-126 \mathrm{~cm}(37 \mathrm{~m})$.

7, 8. 285-4-6, $50-51 \mathrm{~cm}(62 \mathrm{~m})$.

Figures 9, 10 Dictyocha aspera (Lemmermann).

9. $285-3-1,125-126 \mathrm{~cm})$.

10. $285-4-6,50-51 \mathrm{~cm}(62 \mathrm{~m})$.

Figures 11, 12 Dictyocha fibula Ehrenberg s. ampl.

11. 285-3-1, 125-126 cm (37 m).

12. $285-5-6,50-51 \mathrm{~cm}(82 \mathrm{~m})$.

Figure 13 Dictyocha rhombica (Schulz); 285-4-6, 50-51 cm (62 m).

Figure 14 Distephanus sp. cf. D. longispinus (Schulz); 285-5$6,50-51 \mathrm{~cm}(82 \mathrm{~m})$.

Figure 15 Corbisema triacantha (Ehrenberg); 285-5-6, 50-51 $\mathrm{cm}(82 \mathrm{~m})$.

Figure 16 Dictyocha medusa Haeckel; 285-5-6, 50-51 cm (82 $\mathrm{m})$. 


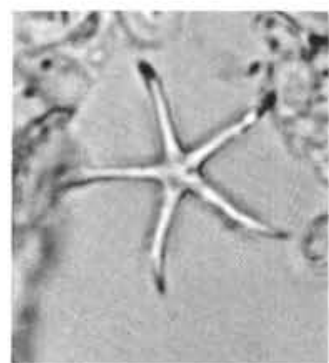

1

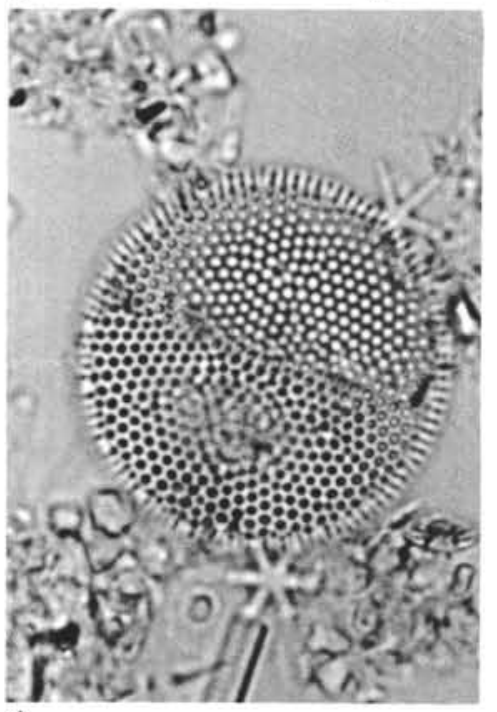

6
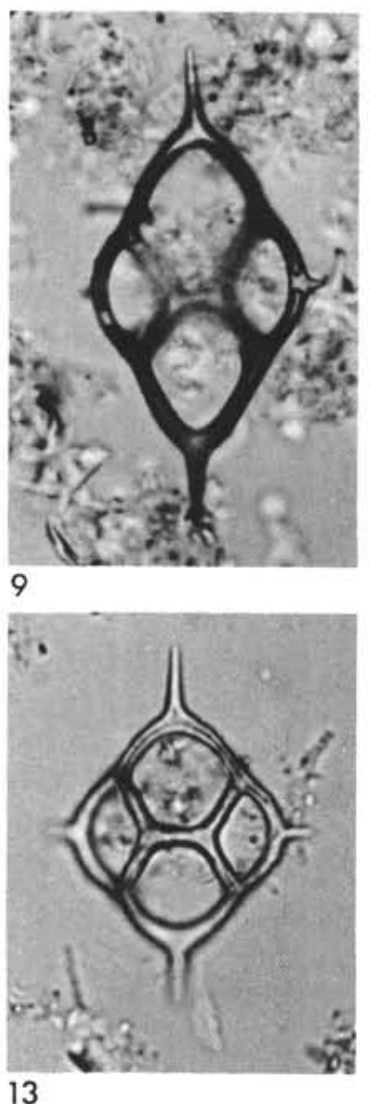

10

14
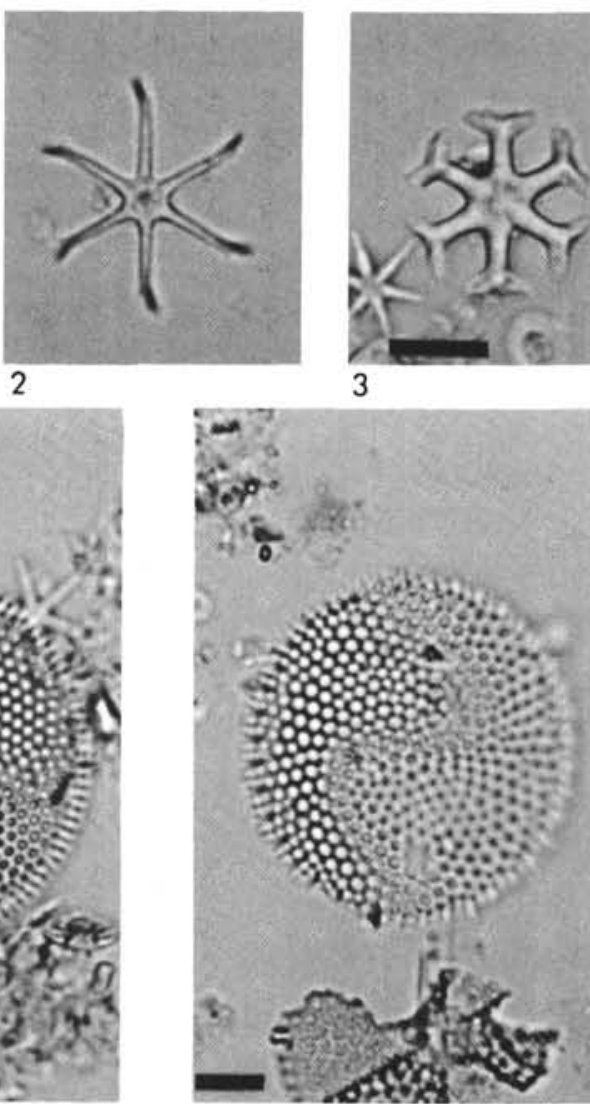

7
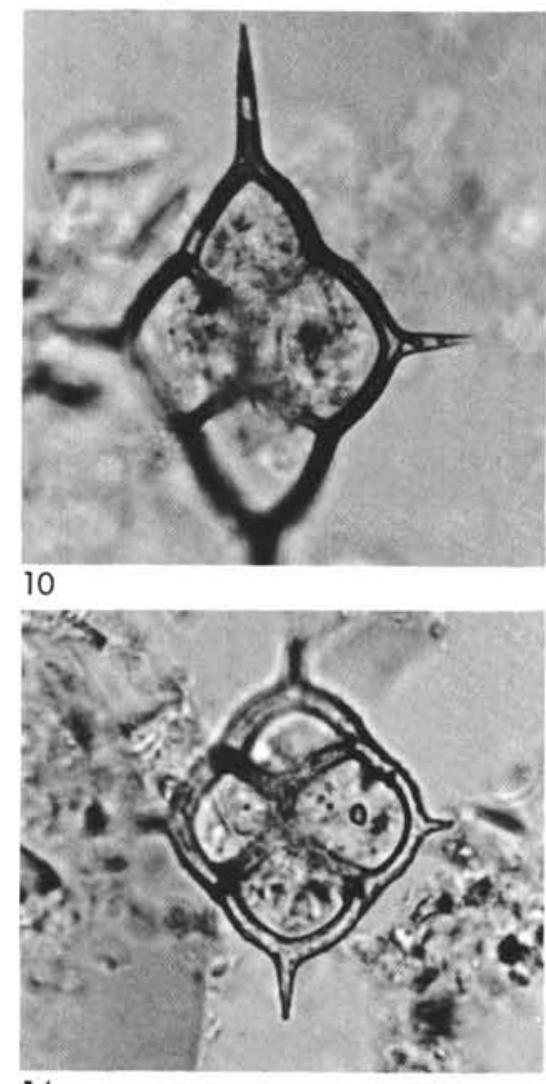
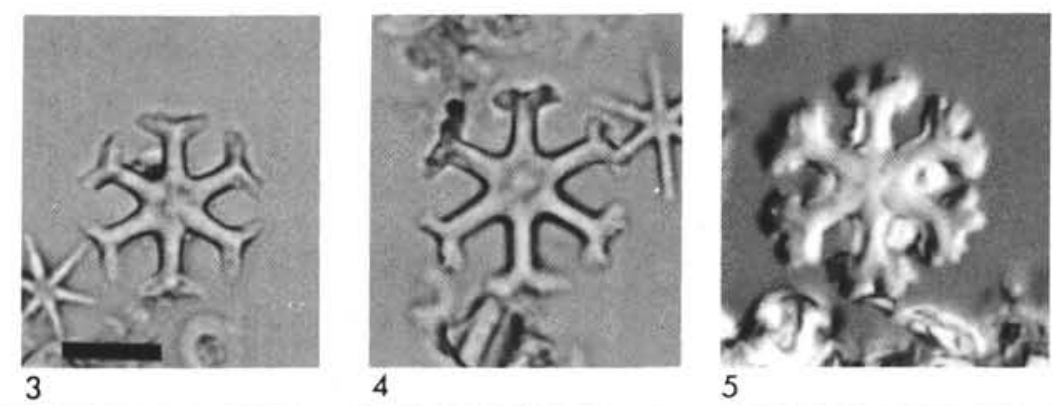

$$
\text { ह }
$$

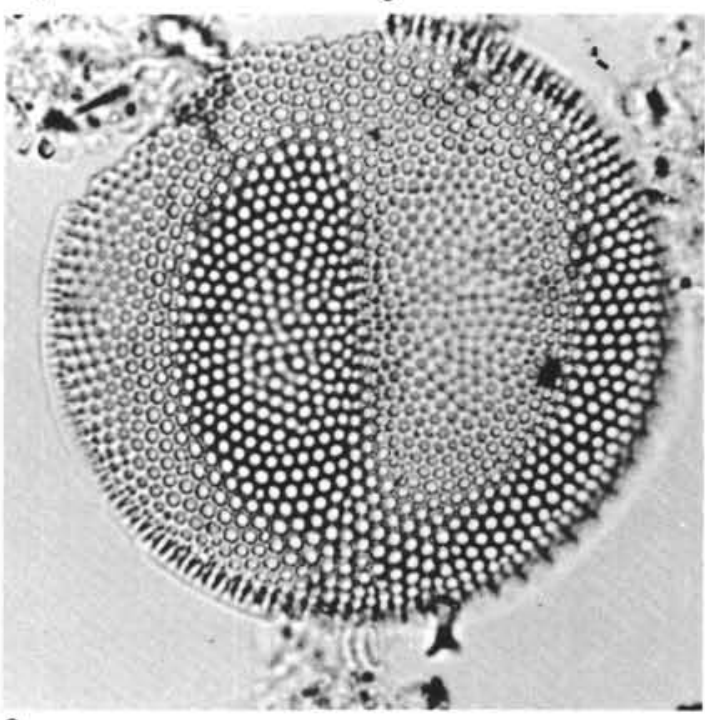

8
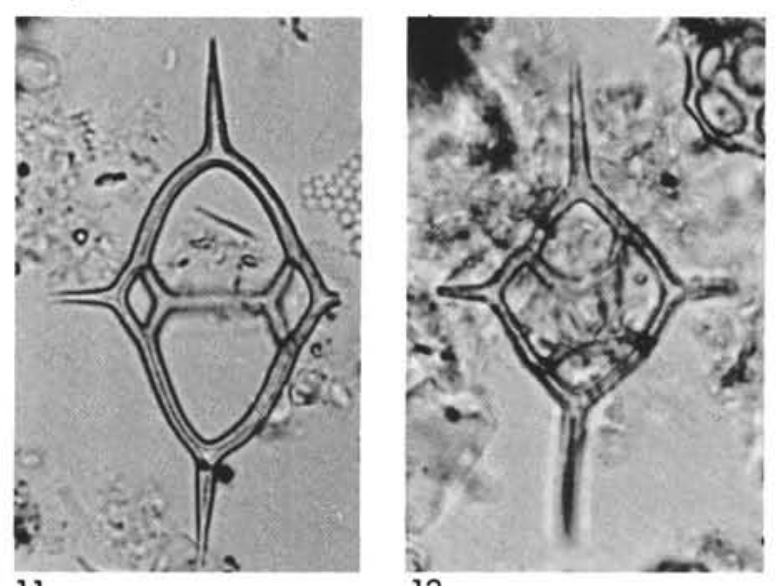

11

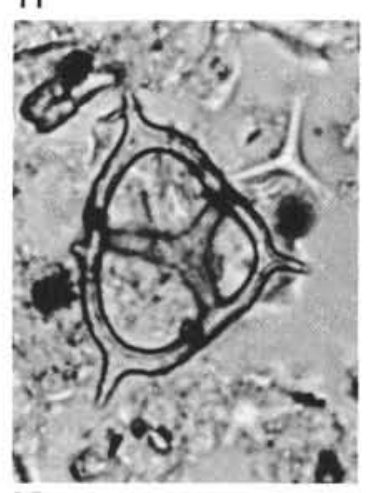

15

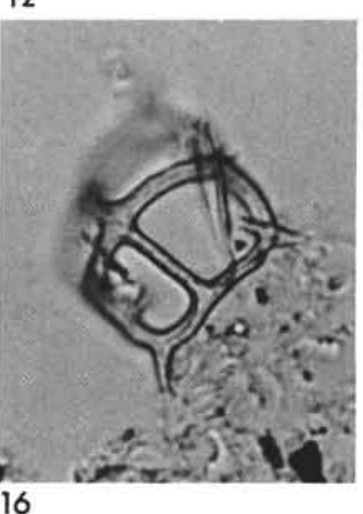

